\title{
Wiktoria Danilewicz-Prokorym
}

Uniwersytet w Białymstoku e mail: wiktoria.prokorym@o2.pl

ORCID: 0000-0002-4572-0816

DOI: $10.15290 /$ mhi.2021.20.01.12

\section{Działania prawne składające się na budowanie wizerunku Białegostoku z marką Esperanto}

\begin{abstract}
ABSTRAKT
Artykuł przedstawia działania prawne Miasta Białegostoku związane z budowaniem jego wizerunku przy wykorzystaniu marki Esperanto na przestrzeni ostatnich lat. Tekst porusza skomplikowaną stronę budowania wizerunku miasta, jaką są działania prawne wykorzystujące atut miasta, którym w przypadku Białegostoku jest marka Esperanto. Działania te podejmowane były zarówno przez organ wykonawczy Gminy - Prezydenta Miasta, jak i organ uchwałodawczy - Radę Miasta. Omówiono w tym zakresie działalność Rady Miasta Białegostoku, działalność związaną z obchodami 100 rocznicy śmierci Ludwika Zamenhofa, organizację Kongresu Esperanto w 2009 r. oraz znaczenie dla omawianego zagadnienia tzw. budżetu partycypacyjnego. Przy analizie tematu wybrano jedynie te działania podejmowanie w Białymstoku, a związane z Ludwikiem Zamenhofem, jego następcami bądź językiem esperanto, które znajdują nie tylko oparcie, ale źródło w aktach prawnych i mają charakter pośrednio lub bezpośrednio prawny. W artykule omówiono zwięźle także aspekt historii życia Ludwika Krzysztofa Zaleskiego Zamenhofa w związku z nadaniem mu Honorowego Obywatelstwa Miasta Białegostoku. Tekst traktując o działaniach prawnych Miasta Białegostoku związanych z budowaniem jego wizerunku przy wykorzystaniu marki Esperanto w perspektywie ostatnich lat porusza ciekawą materi, jaką jest promocja Gminy w oparciu o jedyny na świecie język uniwersalny. Działania prawne opisane w artykule są odzwierciedleniem perspektywy młodego Ludwika Zamenhofa, która doprowadziła do powstania języka esperanto. Tekst łączy dwie materie tj. powstanie języka ponadnarodowego z działaniami prawnymi, które są wykorzystywane do promocji małej ojczyzny jego twórcy.
\end{abstract}




\begin{abstract}
Legal Activities to Build the Image of Bialystok with the Esperanto Brand

The article presents the legal activities of the city of Bialystok related to building its image using the brand Esperanto over the past years. The text deals with the complicated side of building the image of the city which is legal actions using the asset of the city which the case of Bialystok is the brand Esperanto. These actions were taken both by the executive body of the municipality - the Mayor - and the legislative body - the City Council. The following activities were discussed: the activity of the Bialystok City Council, the activity connected with the celebration of the 100th anniversary of Ludwik Zamenhof's death, the organisation of the Esperanto Congress in 2009 and the significance of the so-called participatory budget for the discussed issue. In the analysis of the topic, only those activities undertaken in Bialystok and related to Ludwik Zamenhof, his successors and the Esperanto language were chosen, which are not only based on but have their source in legal acts and are of direct or indirect legal character. The article also briefly discusses the aspect of life history of Ludwik Krzysztof Zaleski Zamenhof in connection with granting him the Honorary Citizenship of the City of Bialystok. The article discusses the legal activities of the city of Bialystok connected with building its image with the use of the Esperanto brand in the perspective of the last years, touching upon an interesting matter which is the promotion of the Municipality on the basis of the only universal language in the world. The legal actions described in the article reflect the perspective of young Ludwik Zamenhoff, which led to the creation of Esperanto language. The text combines two matters, the creation of a supranational language, with legal actions that are used to promote the small homeland of its creator.
\end{abstract}

Słowa kluczowe: promocja, Białystok, wizerunek, Esperanto, działania prawne

Key words: promotion, Białystok, image, Esperanto, legal actions

\title{
Wstęp
}

Celem artykułu jest przedstawienie działań prawnych Miasta Białegostoku związanych z budowaniem jego wizerunku przy wykorzystaniu marki Esperanto. Opracowanie podzielono z uwagi na działalność Rady Miasta Białegostoku, działalność związaną z obchodami 100 rocznicy śmierci Ludwika Zamenhofa, organizację Kongresu Esperanto w 2009 r. oraz znaczenie dla omawianego zagadnienia tzw. budżetu partycypacyjnego. Przy analizie tematu wybrano 
jedynie te działania podejmowanie w Białymstoku, a związane $\mathrm{z}$ Ludwikiem Zamenhofem, jego następcami bądź językiem esperanto, które znajdują nie tylko oparcie, ale źródło w aktach prawnych i mają charakter pośrednio lub bezpośrednio prawny.

\section{Działalność prawna Rady Miasta Białegostoku i Prezydenta Miasta związana $\mathrm{z}$ budowaniem wizerunku Białegostoku z marką Esperanto}

Działalność prawna Rady Miasta Białegostoku związana z budowaniem wizerunku Białegostoku z marką Esperanto obejmuje na przestrzeni ostatnich lat kilka kluczowych przedsięwzięć. O części z nich, w tym uchwałach związanych z 100. rocznicą śmierci Ludwika Zamenhofa, będzie mowa też w dalszej części opracowania. W tym miejscu warto zauważyć, że Rada Miasta korzystając z uprawnienia wynikającego ze statutu Rady Miasta Białegostoku $\$ 10$ ust. 2 pkt 14 i art. 18 ust. 2 pkt 14 Ustawy z dnia 8 marca 1990 r. o samorządzie gminnym $^{1}$ (dalej: usg) zezwalających na nadawanie Radzie Miasta Białegostoku honorowego obywatelstwa ${ }^{2}$, w Uchwale nr XVIII/172/07 z dnia 29 października 2007 r. nadało Honorowe Obywatelstwo Miasta Białegostoku Panu Ludwikowi Krzysztofowi Zaleskiemu Zamenhof - wnukowi Ludwika Zamenhofa ${ }^{3}$. Wyjaśnić trzeba, w kontekście tematu niniejszego opracowania, że Ludwik Krzysztof Zaleski Zamenhof urodził się w Warszawie jako syn Adama Zamenhofa i Wandy z domu Frenkel. Podczas II wojny światowej wraz z najbliższą rodziną został przesiedlony do getta warszawskiego. W sierpniu 1942 r. udało mu się wydostać z Umschlagplatzu, skąd wywieziono go jako nieżywego. Po aryjskiej stronie ukrywał się pod przybranym nazwiskiem Zaleski ${ }^{4}$. Po zakończeniu wojny studiował na Politechnice Warszawskiej, którą ukończył jako inżynier budownictwa. Był profesorem Politechniki w Mediolanie oraz Wyższej Szkoły Architektury w Paryżu, zajmował się głównie technologią betonu sprężonego. Napisał ponad sto publikacji naukowych w języku polskim, francuskim, angielskim i esperanto. W 1993 r. przeszedł na emeryturę i zaczął aktywnie promować esperanto, język stworzony w 1887 r. przez jego dziadka. Uczestniczył w konferencjach i kongresach esperanckich, reprezentując na nich rodzinę Zamenhof. W 2001 r. ukazała się książka pt. Ulica Zamenhofa, wywiad-rzeka, który

$1 \quad$ Dz.U. 1990 nr 16, poz. 95.

2 Statut Rady Miasta $\$ 10$ ust. 2 pkt 14 w związku z art.18 ust. 2 pkt 14 ustawy o samorządzie gminnym.

3 Uchwala Rady Miasta Białegostoku z 29 października 2007 r.

4 J. Jagielski, Przewodnik po cmentarzu żydowskim w Warszawie przy ul. Okopowej 49/51. Z. 1, Kwatery przy Alei Głównej, Warszawa 1996, s. 22-23. 
z Zaleskim-Zamenhofem przeprowadził Roman Dobrzyński. Dwa lata później została wydana wersja esperancka tej książki, którą przetłumaczono na kilkanaście języków ${ }^{5}$. Białystok zwrócił uwagę na osobę wnuka Ludwika Zamenhofa w kontekście propagowania przez niego języka esperanto nadając mu tytuł honorowego obywatela miasta.

Warto zwrócić także uwagę na działania podjęte w związku z budowaniem wizerunku Białegostoku z marką Esperanto bezpośrednio przez Prezydenta Miasta Białegostoku Tadeusza Truskolaskiego, które zmierzały także w sposób co najmniej pośredni do zorganizowania w Białymstoku Światowego Kongresu Esperanto. Prezydent Truskolaski w dniu 20 września 2007 r. odpowiadając na interpelację radnego rady miejskiej w Białymstoku Rafała Rudnickiego, w której radny oczekiwał wyjaśnień w związku z uczestnictwem przedstawicieli miasta w 92. Światowym Kongresie Esperanto, wskazał, iż uczestniczył we wskazanych obchodach w Jokohamie, bowiem wyjazd był znakomitą okazją do spotkania się z przyjaciółmi Białegostoku należącymi do światowej organizacji esperantystów UEA i utwierdzenia ich w przekonaniu, że pomysł organizacji kongresu w Białymstoku w roku jubileuszu - 2009 - dr. Ludwika Zamenhofa jest pomysłem najlepszym z możliwych. Prezydent podał także, że organizacja kongresu jest ogromną szansą zaistnienia w świadomości nie tylko światowej społeczności esperantystów, ale także uczynienia z tej imprezy ogólnego przekazu medialnego o Białymstoku i jego najbliższych okolicach ${ }^{6}$, podkreślając tym samym znaczenie osoby Zamenhofa i języka esperanto dla promocji miasta.

\section{Światowy Kongres Esperanto}

Na rok 2009 przypadła 150. rocznica urodzin Ludwika Zamenhofa. Na swojej dorocznej konferencji w Paryżu UNESCO podjęło uchwałę o rozpoczęciu w dniu 15 grudnia 2008 r. „Roku Zamenhofa”. 150. rocznica urodzin twórcy esperanto i 94 . Światowy Kongres Esperanto, który odbył się w Białymstoku zaowocowały wzmożeniem starań esperantystów o zrealizowanie planu utworzenia w Białymstoku Centrum Esperanto. Szczególnego podkreślenia wymaga, że Światowy Kongres Esperanto jest największą coroczną imprezą esperantystów, organizowaną od 1905 r. niemal nieprzerwanie (z wyjątkiem I i II wojny światowej). Od 1920 r. kongres przygotowuje co roku inny kraj. Liczba uczestników wynosi średnio około 2000 (od 800 do 6000 osób, w zależności od miejsca). Kongresy odbywają się zazwyczaj pod koniec lipca lub na początku sierpnia i trwają 8 dni (otwarcie i zamknięcie imprezy ma miejsce w sobotę). W 2009 r.

5 A. Kłopotowski, Zamenhof wraca do Białegostoku, www.gazeta.pl (17.12.2007).

6 Odpowiedź Prezydenta Miasta Białegostoku z dnia 20 września 2007 r. na interpelację radnego Rafała Rudnickiego. 
w Światowym Kongresie Esperanto w Białymstoku uczestniczyło 1860 osób ${ }^{7}$. W rezolucji uczestnicy kongresu podkreślili m.in., że Zamenhof zasługuje na większą uwagę nie tylko jako twórca języka, ale również „jako osoba, która dążyła do rzeczywistego braterstwa ludzi na podstawie pełnego i wzajemnego zrozumienia". Uczestnicy kongresu zwracali też uwagę na wkład Zamenhofa $\mathrm{w}$ „starania dotyczące zniesienia nienawiści między członkami różnych religii, zniesienia uprzedzeń rasowych oraz odrzucenia wojny jako sposobu rozwiązywania sporów"8.

\section{Działania prawne upamiętniające 100. rocznicę śmierci Ludwika Zamenhofa}

Zakres omawianego zagadnienia wymaga także wskazania, jakie działania składające się na budowanie wizerunku Białegostoku z marką Esperanto zostały podjęte $\mathrm{w}$ związku z 100. rocznicą śmierci Ludwika Zamenhofa (Zamenhof zmarł 14 kwietnia 1917 r.). Miłośnicy esperanto przedstawiciele władz Białegostoku i mieszkańcy upamiętnili twórcę esperanto w szerokim zakresie. Warto podnieść także, iż władze Białegostoku chciały ogłosić rok 2017 Rokiem Zamenhofa, jednak nie udało się podjąć stosownej uchwały w uwagi na brak zgody radnych i liczne głosy „przeciw”, które w efekcie doprowadziły do odrzucenia propozycji Prezydenta Miasta ${ }^{9}$. Wówczas zastępca prezydenta Białegostoku Rafał Rudnicki wskazał „żałujemy, że radni w grudniu nie zgodzili się na propozycję prezydenta, ale mamy patronat UNESCO i dużo dobrej woli, by tę rocznicę starać się upamiętniać w każdy możliwy sposób" - powiedział PAP ${ }^{10}$. Rada Miasta Białegostoku przyjęła jednak na sesji w dniu 24 kwietnia 2017 r. stanowisko, w którym uczciła pamięć twórcy języka esperanto ${ }^{11}$. W przyjętej uchwale ${ }^{12}$ przypomniano życie i dzieło Zamenhofa - twórcy sztucznego, międzynarodowego języka esperanto. Wskazano „Ludwik Zamenhof urodził się, dorastał i wychowywał w środowisku wielonarodowościowej społeczności Białegostoku, które stało się dla niego inspiracją do stworzenia języka ponadnarodowego. Uważał, że ludzi dzieli przede wszystkim bariera językowa, która wywołuje konflikty i nieporozumienia. Wierzył, że idea esperanta

7 Informacja Departamentu Kultury, Promocji i Sportu Urzędu Miejskiego w Białymstoku z dnia 3 sierpnia $2009 \mathrm{r}$.

8 https://naukawpolsce.pap.pl/aktualnosci/news\%2C364213\%2Czakonczyl-sie-swiatowy-kongres-esperanto-w-bialymstoku.html

9 https://www.wrotapodlasia.pl/pl/region_i_gospodarka/wiadomosci/bialystok/nie-bedzie-roku-zamenhofa-w-bialymstoku-radni-odrzucili-propozycje-prezydenta.html

$10 \mathrm{https} / / /$ kultura.gazetaprawna.pl/artykuly/1034930,bialystok-esperanto-ludwik-zamenhof.html

11 https://dzieje.pl/kultura-i-sztuka/rada-miasta-bialegostoku-uczcila-pamiec-tworcy-esperanto-ludwika-zamenhofa

12 Stanowisko Rady Miasta Białegostoku z dnia 24 kwietnia 2017 w sprawie uczczenia pamięci Ludwika Zamenhofa w 100. rocznicę śmierci. 
zjednoczy nie tylko esperantystów, ale stanie się siłą jednoczącą wszystkich ludzi” - głosiła uchwała. Uroczystości zaplanowano na cały $\operatorname{rok}^{13}$. W efekcie w 2017 r. zorganizowano w Białymstoku i bezpośrednio w związku ze wskazaną rocznicą Test Wiedzy o Historii Białegostoku (19 lutego 2017 r.), festiwal/przegląd muzyki wykonywanej w języku esperanto i przez esperantystów (kwiecień 2017 r.), konferencję popularnonaukową, której organizatorem była Książnica Podlaska (12 maja 2017 r.) pod tytułem „Esperanto. Język - Idea - Twórca”, Grę Miejską - Poznaj Białystok 2017 - Śladami Zamenhofa (VIII edycja gry terenowej, podczas Europejskiej Nocy Muzeów, 20 maja 2017 r.), inscenizację przyjazdu do Białegostoku uczestników 19. Światowego Kongresu Esperanto, który odbył się w 1927 r. w Wolnym Mieście Gdańsku (7 sierpnia 2017 r.) pod hasłem „1927-2017. Inscenizacja”, serię - „Spacerów z Ludwikiem Zamenhofem” - pierwszy spacer Wieża Babel (kwiecień 2017 r.), drugi spacer Esperantyści w Białymstoku (lipiec 2017 r.), trzeci spacer Droga do szkoły, grudzień 2017 r. W celu upamiętnienia setnej rocznicy śmierci Ludwika Zamenhofa wydano także polsko-esperancką książkę kucharską Obiad u Zamenhofów (czerwiec 2017 r.), wykonano „Mural Esperanto” czyli wielkoformatowe malowidło inspirowane życiem Ludwika Zamenhofa oraz językiem esperanto (fasada budynku przy ul. Warszawskiej 19), (termin realizacji miał miejsce w połowie 2017 r.), wydano reprint pierwszego przewodnika po Białymstoku w języku esperanto opracowanego przez Jakuba Szapiro w latach 1923 i 1931 (termin realizacji: 2017 r.) pt. Gvidilo tra Bialystok, la naskurbo de la Majstro (reprint), kontynuowano rozpoczęte w $2016 \mathrm{r}$. warsztaty filmowe dla dzieci i młodzieży prowadzone przez Elwirę Małyszko (premiera filmu 15 grudnia 2017 r.) pt. „Ludwik animowany”, zorganizowano także przegląd filmów zrealizowanych w języku esperanto, a w programie znalazły się pełnometrażowe filmy fabularne i dokument zrealizowane w języku esperanto bądź poświęcone ruchowi esperanckiemu. Wyemitowano także spot promujący Białystok pt. „W Białymstoku mówimy w esperanto" z udziałem przedstawicieli kultury, nauki, samorządu i mediów. Kolejnymi działaniami dla upamiętnienia 100. rocznicy śmierci Zamenhofa podjętymi w 2017 r. były wydanie zbioru poezji Wiesława Kazaneckiego w języku esperanto, wykonanie okazjonalnych gadżetów (koszulki, puzzle) z reprodukcją muralu autorstwa Andrzeja Muszyńskiego, przeprowadzenie kursu języka esperanto tj. cyklu lekcji przybliżających język esperanto, realizowanego we współpracy z Polskim Radiem Białystok, zorganizowanie warsztatów języka esperanto dla dzieci i produkcja spektaklu w języku esperanto przez Białostocki Teatr Lalek, termin realizacji: 2017 r. ${ }^{14}$ Powyższe zestawienie obrazuje nie tylko szeroki

13 https://dzieje.pl/kultura-i-sztuka/obchody-100-rocznicy-smierci-ludwika-zamenhofa-tworcy-jezyka-esperanto

14 Informacja prasowa Departamentu Kultury, Promocji i Sportu Urzędu Miejskiego w Białymstoku, styczeń 2017 r. 
zakres działań Białegostoku związanych z promowaniem miasta jako powiązanego ściśle z językiem esperanto, ale także różnorodność powyższych działań.

\section{Współpraca Miasta Białegostoku z Białostockim Towarzystwem Esperantystów}

W zakresie działań prawnych składających się na budowanie wizerunku Białegostoku z marką Esperanto mieści się też współpraca Miasta Białegostoku z Białostockim Towarzystwem Esperantystów ${ }^{15}$. Towarzystwo prowadzi działalność edukacyjno-kulturalną przybliżając wiedzę o innych krajach i kulturach oraz komunikację międzynarodową przy pomocy języka esperanto. Organizacja nie zatrudnia pracowników, wszystkie funkcje pełnione są przez wolontariuszy. W ramach działalności statutowej rozwijana jest działalność kulturalno-oświatowa i pogłębianie wiedzy o innych narodach i krajach przy zastosowaniu esperanta, nauczany jest język esperanto, popularyzowane jego wartości użytkowe i wychowawcze, za pomocą esperanto propagowane są idee zbliżenia między narodami i pokojowej współpracy, język esperanto wykorzystywany jest do popularyzowania historii i kultury polskiej, a w szczególności kultury regionu północno-wschodniego za granicą, zaspokajane są potrzeby członków Białostockiego Towarzystwa Esperantystów w zakresie doskonalenia znajomości języka esperanto. Największą imprezą przygotowywaną przez Białostockie Towarzystwo Esperantystów we współpracy ze Światowym Związkiem Esperantystów i Polskim Związkiem Esperantystów był wymieniony Światowy Kongres Esperanto, który odbył się w 2009 r. w Białymstoku. Wielką rolę w przygotowaniach do 94 Światowego Kongresu Esperanto odgrywało Miasto Białystok. To wówczas prezydent i radni, przy życzliwym zainteresowaniu marszałka Województwa Podlaskiego, zdecydowali wspólnie o utworzeniu przy historycznym trakcie ulicy Warszawskiej, w popadającym w ruinę budynku, Centrum Esperanto.

\section{Centrum Esperanto im. Ludwika Zamenhofa}

Nie sposób wyczerpać tematu opracowania bez szerokiego omówienia działań Miasta Białegostoku w związku z powstaniem i organizacją Centrum im. Ludwika Zamenhofa. Utworzono je formalnie na wniosek Prezydenta Miasta Białegostoku z okazji wyżej wspomnianego, organizowanego w 2009 r. 94. Światowego Kongresu Esperanto. Początkowo Centrum im. Ludwika Zamenhofa było oddziałem Białostockiego Ośrodka Kultury. Jego oficjalne otwarcie miało miejsce w dniu 21 lipca 2009 r. W styczniu 2011 r.

15 https://espero.bialystok.pl/pl/projekty 
Centrum im. Ludwika Zamenhofa stało się samodzielną placówką kultury. Po sześciu latach działalności, w styczniu 2017 r. - zgodnie z Uchwałą nr XXVI /406/16 Rady Miasta Białegostoku z dnia 24 października 2016 r. w sprawie połączenia miejskich samorządowych instytucji kultury Centrum im. Ludwika Zamenhofa (dalej: CLZ) ponownie weszło w skład Białostockiego Ośrodka Kultury ${ }^{16}$. W kontekście powstania i dalszego funkcjonowania CLZ przeanalizowano uwarunkowania prawne odnoszące się zarówno do fazy procesu projektowego, jak i do późniejszego okresu. W zakresie przepisów związanych $\mathrm{z}$ realizacją projektu ustalono, że jest ono zgodne z Rozporządzeniem Rady (WE) nr 1083/2006 z dnia 11 lipca 2006 r. ustanawiającym przepisy ogólne dotyczące Europejskiego Funduszu Rozwoju Regionalnego, Europejskiego Funduszu Społecznego oraz Funduszu Spójności i uchylające Rozporządzenie (WE) nr 1260/1999 (Dz.Urz. UE L 210/25 z 31.07.2006 r.), Rozporządzeniem (WE) nr 1080/2006 Parlamentu Europejskiego i Rady w sprawie Europejskiego Funduszu Rozwoju Regionalnego z dnia 5 lipca 2006 r. w sprawie Europejskiego Funduszu Rozwoju Regionalnego i uchylające Rozporządzenie (WE) nr 1783/1999 (Dz.Urz. UE L 210/1 z 31.07.2006 r.), Rozporządzeniem Komisji (WE) nr 1828/2006 z dnia 8 grudnia 2006 r. ustanawiającym szczegółowe zasady wykonania Rozporządzenia Rady (WE) nr 1083/2006 ustanawiającego przepisy ogólne dotyczące Europejskiego Funduszu Rozwoju Regionalnego, Europejskiego Funduszu Społecznego oraz Funduszu Spójności oraz Rozporządzenia (WE) nr 1080/2006 Parlamentu Europejskiego i Rady w sprawie Europejskiego Funduszu Rozwoju Regionalnego. Jednocześnie zweryfikowano, że inicjatywa jest zgodna z przepisami Prawa Polskiego tj. Ustawą z dnia 6 grudnia 2006 r. o zasadach prowadzenia polityki rozwoju (Dz.U. z dnia 11 grudnia 2006 r.), Ustawą z dnia 29 stycznia 2004 r. Prawo zamówień publicznych (Dz.U. 2006 nr 164, poz. 1163, z późn. zm.), Ustawą z dnia 30 czerwca 2005 r. o finansach publicznych (Dz.U. $2005 \mathrm{nr}$ 249, poz. 2104, z poźn. zm.), Ustawą z dnia 27 kwietnia 2001 r. Prawo ochrony środowiska (Dz.U. 2006 nr 129, poz. 902, z późn. zm.), Ustawą z dnia 29 września 1994 r. o rachunkowości (Dz.U. 2002 nr 76, poz. 694, z późn. zm.), Ustawą z dnia 11 marca 2004 r. o podatku od towarów i usług (Dz.U. 2004 nr 249, poz. 535, z późń. zm.). Przed otwarciem placówki zostało sporządzone Studium Wykonalności Projektu Zakupu wyposażenia na potrzeby Centrum Esperanto im. Ludwika Zamenhofa w Białymstoku, w którym to dokumencie wskazano na następujące dziedziny oddziaływania powołanej instytucji: demokrację, kształcenie ponadnarodowe, skuteczność pedagogiczną, wielojęzyczność, prawa językowe, różnorodność językową i emancypację. W ramach aspektu demokracji wskazano, że system komunikacyjny, który przez całe życie daje przywileje niektórym ludziom, a żąda od

16 Informacja Centrum Ludwika Zamenhofa, www.centrumzamenfofa.pl 
innych, aby inwestowali przez lata, by osiągnąc niezbyt wysoki stopień umiejętności, jest z gruntu niedemokratyczny. Chociaż jak każdy język, esperanto nie jest doskonałe, to ogromnie przewyższa każdego rywala w sferze równości ogólnoświatowej komunikacji. Esperantyści są zdania, że nierówność językowa prowadzi za sobą nierówność komunikacyjną na wszystkich poziomach, a na poziomie międzynarodowym głównie. Są ruchem opowiadającym się za demokratycznym sposobem komunikowania $\operatorname{się}^{17}$. Co do kształcenia ponadnarodowego wskazano, że każdy język etniczny związany jest z określoną kulturą i narodem. Uczeń studiujący esperanto uczy się o świecie bez granic, w którym każdy kraj prezentuje się jako dom rodzinny. Esperantyści są zdania, że kształcenie na bazie któregokolwiek języka etnicznego połączone jest $\mathrm{z}$ jego określoną pozycją w świecie. Opowiadają się za kształceniem ponadnarodowym ${ }^{18}$. $\mathrm{W}$ zakresie skuteczności pedagogicznej podano, że tylko niewielki procent z tych, którzy studiują obcy język, wykorzystuje go należycie. Pełne opanowanie esperanto możliwe jest nawet przez samokształcenie. Różne badania informują o jego propedeutycznych skutkach w nauce innych języków. Zaleca się również esperanto jako istotną część kursu dla wyrobienia językowej świadomości uczniów. Esperantyści są zdania, że trudności w opanowaniu języków etnicznych zawsze stanowią przeszkodę dla wielu uczniów, którzy jednak mogliby osiągnąć korzyść ze znajomości drugiego języka. Wielojęzyczność winna być rozumiana $\mathrm{w}$ ten sposób, iż wspólnota esperancka jest jedną z nielicznych w skali światowej, której członkowie bez wyjątku posiedli znajomość dwóch języków. Każdy członek tej wspólnoty podjął zadanie uczyć się przynajmniej jednego języka obcego do poziomu pozwalającego na swobodną wymianę myśli. Prowadzi to często do pogłębiania wiedzy, więc i do umiłowania wielu języków, a ogólnie do rozwinięcia szerszego osobistego horyzontu myślowego. Esperantyści są zdania, że użytkownicy wszystkich języków - „dużych i małych”, powinni mieć realną szansę przyswojenia drugiego języka na wysokim poziomie $^{19}$. Nierówne traktowanie wartości różnych języków jest stałym zagrożeniem dla języków etnicznych lub bezpośrednią supremacją nad dużą częścią ludzkości. We wspólnocie esperanckiej, użytkownicy języków „dużych i małych”, oficjalnych i nieoficjalnych, spotykają się na terenie neutralnym, dzięki wzajemnej woli znalezienia kompromisu. Taka równowaga między prawami językowymi i odpowiedzialnością dostarcza precedensu, aby zmieniać i oceniać inne rozwiązania wynikające $z$ nierówności językowej i powstałych na tym tle konfliktów. Esperantyści są zdania, że dominacja językowa podważa gwarancje, wyrażone w wielu dokumentach międzynarodowych, o równorzędnym

17 Studium Wykonalności Projektu Zakup wyposażenia na potrzeby Centrum Esperanto im. Ludwika Zamenhofa w Białymstoku, Białystok, wrzesień 2008 r., s. 85. 
traktowaniu każdego języka ${ }^{20}$. W zakresie różnorodności językowej wskazać należy, że rządy niektórych krajów są skłonne traktować dużą różnorodność językową w świecie jako przeszkodę w komunikacji i rozwoju. Dla wspólnoty esperanckiej różnorodność językowa jest stałym i koniecznym źródłem bogactwa. W następstwie, każdy język, jak każda istota żyjąca jest wartościowa sama przez się i godna ochrony oraz wsparcia. Esperantyści są zdania, że polityka komunikacji i rozwoju nieoparta na poszanowaniu i wsparciu wszystkich języków skazuje na zagładę większość języków świata. Emancypację należy rozumieć w ten sposób, że każdy język wyzwala i więzi swoich użytkowników, dając im możliwość komunikowania się między sobą - stanowiąc jednocześnie przeszkodę komunikacyjną z innymi. Zaplanowany jako uniwersalne narzędzie komunikowania się język esperanto jest jednym $\mathrm{z}$ wielkich funkcjonujących projektów ludzkiej emancypacji - projektem umożliwiającym każdemu człowiekowi jako indywidualności uczestniczenie w ludzkiej wspólnocie, z zachowaniem silnych korzeni w swojej miejscowej kulturze i językowej tożsamości, lecz nie ograniczanemu $z$ ich strony ${ }^{21}$.

\section{Działania prawne składające się na budowanie wizerunku Białegostoku z marką Esperanto a budżet obywatelski}

Od 2014 r. mieszkańcy Białegostoku mają możliwość zgłaszania projektów do Budżetu Obywatelskiego Miasta Białegostoku. Budżet obywatelski w judykaturze prawniczej przyjmuje się nazywać budżetem partycypacyjnym nazwanym tak od słowa partycypacja czyli uczestniczenie, uczestnictwo, udział jednostek w większej grupie, formacji, projekcie czy instytucji ${ }^{22}$.

Pierwszy budżet obywatelski na świecie powstał w brazylijskim Porto Alegre w 1989 r., w Polsce niejako prekursorem było miasto Sopot, które w 2011 r. wprowadziło do swojej procedury uchwalania budżetu zasady budżetu obywatelskiego $^{23}$. Dzisiaj dla rad gmin podejmujących uchwały w sprawie budżetów obywatelskich najważniejsze stały się ust. 2, 6 i 7 art. 5a usg ${ }^{24}$. Przepisy te zawierają upoważnienie do przyjęcia odpowiedniej uchwały lub zawierają dodatkowe wymogi co do treści takiej uchwały ${ }^{25}$. W Białymstoku obowiązuje określona praktyka realizacji budżetu obywatelskiego. Zgłaszane inwestycje są oceniane najpierw pod względem formalnym przez Zespół ds. Budżetu Oby-

20 Ibidem, s. 87.

21 Ibidem, s. 88 .

22 https://sjp.pwn.pl/slowniki/partycypacja.html

23 M. Gerwin, M. Grabkowska, Budżet Obywatelski, [w:] Partycypacja. Przewodnik Krytyki Politycznej, Warszawa 2012, s. 100.

24 Dz.U. $1990 \mathrm{nr}$ 16, poz. 95.

25 https://www.rp.pl/Finanse/303129985-Budzety-obywatelskie-w-gminach-na-nowych-zasadach. html 
watelskiego powołany przez Prezydenta Miasta składający się z przedstawicieli Prezydenta Miasta, urzędu miasta, rady miasta, mieszkańców oraz organizacji społecznych. Ocenia on projekty pod kątem formalnym sprawdzając m.in. czy ich realizacja będzie odbywać się na terenach gminnych oraz czy ich powstanie będzie spełniało obowiązek ogólnodostępności. Projekt taki po pozytywnej weryfikacji formalnej jest poddawany pod głosowanie wszystkich mieszkańców miasta.

W Białymstoku budżet obywatelski funkcjonuje od 2014 r. Co roku kwota przeznaczana na realizację tej formy udziału obywateli $\mathrm{w}$ inwestycjach $\mathrm{z}$ budżetu miasta jest zwiększana i obecnie wynosi 10 milionów złotych. Wyniki głosowania mieszkańców nad budżetem obywatelskim są wpisywane przez Prezydenta Miasta Białegostoku do projektu budżetu miasta, który co roku jest przedkładany Radzie Miasta do dnia 15 listopada w celu jego uchwalenia w brzmieniu przedstawionym przez organ wykonawczy miasta bądź z poprawkami naniesiony przez radnych. Kilkuletnia tradycja budżetu obywatelskiego Miasta Białegostoku wskazuje, że radni szanują wybór mieszkańców, nigdy nie zostały zgłoszone poprawki do budżetu, które dotyczyłyby wskazanych przez obywateli inwestycji w ramach budżetu partycypacyjnego. Budżet obywatelski, oprócz realizowania inwestycji takich jak drogi, boiska, ścieżki rowerowe czy place zabaw, okazał się także miejscem promocji miasta poprzez idee wyznawane przez Ludwika Zamenhofa oraz bliskie językowi esperanto. Do budżetu obywatelskiego na 2017 r. została bowiem zgłoszona budowa pomnika Młodego Zamenhofa, który zgodnie z treścią wniosku złożonego do budżetu obywatelskiego powstał w okolicach ratusza przy Rynku Kościuszki w Białymstoku. Projekt ten należał do kategorii budżet osiedlowy dla osiedli centrum, a koszt jego realizacji został wyliczony na kwotę 180 tysięcy złotych. Efekt działań podjętych w ramach budżetu obywatelskiego $\mathrm{w}$ postaci pomnika Młodego Zamenhofa znalazł się na liście atrakcji szlaku Zamenhof/Esperanto-Obiekto ${ }^{26}$.

\section{Zakończenie}

Promocja Miasta Białegostoku poprzez markę Esperanto jest jednym z głównych kierunków promocji Gminy. Działania prawne podejmowane w tym zakresie skupiają się przede wszystkim na działalności edukacyjno-kulturalnej przybliżając wiedzę na temat twórcy języka esperanto oraz działalności wspierającej komunikację przy pomocy języka esperanto. Głównym działaniem prawnym mającym na celu promocję miasta poprzez markę Esperanto było powołanie Centrum Esperanto im. Ludwika Zamenhofa w Białymstoku. Centrum stało się pomostem łączącym białostockie organizacje pozarządowe oraz miejscem

26 P. Dzienis, Uniwersalny jak Esperanto, „Gazeta Prawna” 2019 (21.05), wydanie nr 9. 
organizacji kursów, spotkań i konferencji pokazujących Białystok takim, jaki był w czasach Ludwika Zamenhofa. Pełni ono także rolę archiwum esperanckiego poprzez zbieranie z całego świata książek i innych zbiorów związanych z historią ruchu esperanckiego. Nauka języka esperanto, która odbywa się w Centrum stanowi także sposób na promocję Białegostoku i lokalnej kultury.

\section{Bibliografia}

Dmowski S., Rudnicki S., Komentarz do Kodeksu cywilnego, Warszawa 2009.

Dzienis P., Uniwersalny jak Esperanto, „Gazeta Prawna” 2019 (21.05), wydanie nr 9.

Gerwin M., Grabkowska M., Budżet Obywatelski, [w:] Partycypacja. Przewodnik Krytyki Politycznej, Warszawa 2012.

Informacja Departamentu Kultury, Promocji i Sportu Urzędu Miejskiego w Białymstoku $\mathrm{z}$ dnia 3 sierpnia $2009 \mathrm{r}$.

Informacja prasowa Departamentu Kultury, Promocji i Sportu Urzędu Miejskiego w Białymstoku, styczeń $2017 \mathrm{r}$.

Jagielski J., Przewodnik po cmentarzu żydowskim w Warszawie przy ul. Okopowej 49/51. Z. 1, Kwatery przy Alei Głównej, Warszawa 1996.

Odpowiedź Prezydenta Miasta Białegostoku z dnia 20 września 2007 r. Odpowiedź na interpelację radnego Rafała Rudnickiego.

Plan zamierzeń merytorycznych na 2012 rok Centrum im. Ludwika Zamenhofa z dnia 9 stycznia 2012 roku.

Sprawozdanie merytoryczne za 2011 rok Centrum im. Ludwika Zamenhofa z dnia 9 lutego 2012 roku, Dział 921, Rozdz. 92113.

Sprawozdanie Prezydenta Miasta Białegostoku z działalności miejskich instytucji kultury w 2012 roku oraz zamierzenia na rok 2013 z dnia 4 kwietnia 2013 roku, numer BKO-V.402.9.5.2013.

Stanowisko Rady Miasta Białystok z dnia 24 kwietnia 2017 roku w sprawie uczczenia pamięci Ludwika Zamenhofa w 100. rocznicę śmierci.

Strategia promocji i komunikacji marketingowej, proinwestycyjnej, turystycznej i wewnętrznej Miasta Białegostoku z 15 czerwca 2009 r.

Studium Wykonalności Projektu. Zakup wyposażenia na potrzeby Centrum Esperanto im. Ludwika Zamenhofa w Białymstoku, Białystok, Wrzesień 2008 r.

\section{Źródła internetowe}

www.centrumzamenhofa.pl

https://naukawpolsce.pap.pl/aktualnosci/news\%2C364213\%2Czakonczyl-sie-swiatowy-kongres-esperanto-w-bialymstoku.html

https://naukawpolsce.pap.pl/aktualnosci/news\%2C364213\%2Czakonczyl-sie-swiatowy-kongres-esperanto-w-bialymstoku.htm 
https://kultura.gazetaprawna.pl/artykuly/1034930,bialystok-esperanto-ludwikzamenhof.html

https://dzieje.pl/kultura-i-sztuka/rada-miasta-bialegostoku-uczcila-pamiec-tworcyesperanto-ludwika-zamenhofa

https://dzieje.pl/kultura-i-sztuka/obchody-100-rocznicy-smierci-ludwika-zamenhofatworcy-jezyka-esperanto

https://sjp.pwn.pl/slowniki/partycypacja.html

https://www.rp.pl/Finanse/303129985-Budzety-obywatelskie-w-gminach-na-nowychzasadach.html

https://espero.bialystok.pl

https://www.wrotapodlasia.pl/pl/region_i_gospodarka/wiadomosci/bialystok/nie-bedzie-roku-zamenhofa-w-bialymstoku-radni-odrzucili-propozycje-prezydenta.html

http://orzeczenia.nsa.gov.pl/doc/25517E595C

\section{Orzecznictwo}

Wyrok Sądu Najwyższego z dnia 15 października 2009 r., I CSK 72/09, OSNC 2010, nr A, poz. 29.

Wyrok Sądu Okręgowego w Gliwicach z dnia 24 czerwca 2014 r., sygn. akt II C 226/13.

Wyrok Sądu Najwyższego z dnia 20 maja 2004 sygnatura II CK 330/03, niepubl.

Wyrok Sądu Najwyższego - Izba Cywilna z dnia 7 października 2009 r. III CSK 39/09, LEX.

\section{STRESZCZENIE}

Celem artykułu jest przedstawienie działań prawnych Miasta Białegostoku związanych z budowaniem jego wizerunku przy wykorzystaniu marki Esperanto. W opracowaniu omówiono działalność Rady Miasta Białegostoku, działalność związaną z obchodami 100 rocznicy śmierci Ludwika Zamenhofa, organizację Kongresu Esperanto w 2009 r. oraz znaczenie dla omawianego zagadnienia tzw. budżetu partycypacyjnego na przestrzeni ostatnich lat. Opisując działania prawne dotyczące wykorzystania marki Esperanto wzięto pod uwagę także działania Prezydenta Miasta Białegostoku jako organu wykonawczego Miasta. Przy analizie przedmiotowego tematu wybrano jedynie te działania podejmowanie w Białymstoku, a związane z Ludwikiem Zamenhofem, jego następcami bądź językiem esperanto, które znajdują nie tylko oparcie, ale źródło w aktach prawnych i mają charakter pośrednio lub bezpośrednio prawny. Opracowanie zmierza do wykazania, że promocja Miasta Białegostoku poprzez markę Esperanto jest jednym z głównych i kluczowych kierunków promocji gminy. Działania prawne podejmowane w tym zakresie skupiają się przede wszystkim na działalności edukacyjno-kulturalnej przybliżając wiedzę na temat twórcy języka esperanto oraz działalności wspierającej komunikację przy pomocy języka esperanto. Głównym działaniem prawnym i jednym z kluczowych zadań mających na celu promocję Miasta Białegostoku poprzez markę Esperanto było 
powołanie Centrum Esperanto im. Ludwika Zamenhofa w Białymstoku. Centrum stało się pomostem łączącym białostockie organizacje pozarządowe oraz miejscem organizacji kursów, spotkań i konferencji pokazującym Białystok takim, jaki był w czasach Ludwika Zamenhofa w związku z czym jego powołaniu i działalności poświęcono znaczną część opracowania. Wykorzystanie marki Esperanto w ostatnich latach było jednym z głównych kierunków działalności promocyjnej miasta Białegostoku.

\section{SUMMARY}

\section{Legal Activities to Build the Image of Bialystok with the Esperanto Brand}

The aim of the article is to present legal activities of the City of Białystok connected with building its image using the brand Esperanto. The article discusses the activity of the City Council of the City of Białystok, the activity connected with the celebration of the 100th anniversary of Ludwik Zamenhof's death, the organisation of the Esperanto Congress in 2009 as well as the significance of the so-called participatory budget for the discussed issue in recent years. While describing legal activities concerning the use of the Esperanto brand, the activities of the Mayor of the City of Białystok as the executive body of the city were also taken into consideration. In analyzing this topic, only those activities undertaken in Bialystok and related to Ludwik Zamenhof, his successors, or the Esperanto language have been chosen that are not only based on, but have their source in legal acts and have a direct or indirect legal character. The study aims to show that the promotion of the city of Bialystok through the Esperanto brand is one of the main and key directions of the municipality's promotion. The legal activities undertaken in this field are mainly focused on educational and cultural activities, bringing knowledge about the creator of Esperanto language and activities supporting communication using Esperanto language. The main legal activity and one of the key tasks aimed at promoting the city of Bialystok through the Esperanto brand was the establishment of the Ludwik Zamenhof Esperanto Centre in Bialystok. The centre has become a bridge between Bialystok's nongovermental organisations, as well as a place where courses, meetings and conferences are organised, showing Bialystok as it was in Ludwik Zamenhof's times. The use of the Esperanto brand in recent years has been one of the main directions of the promotional activities of the city of Bialystok. 